\title{
Influence of Packaging Design, Promotion and Brand Image on Consumer Buying Interest (Study Case of Consumers Glek-Glek Tea Nganjuk)
}

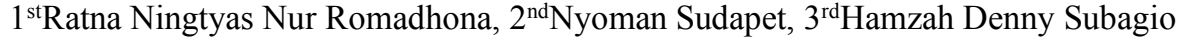 \\ Narotama University, Indonesia \\ dhonna99@gmail.com
}

\begin{abstract}
This study aims to determine the effect of packaging design, promotion and brand image on consumer buying interest in NganjukGlek-Glek Tea. The population used in this study were consumers of Glek-Glek Tea Nganjuk with 100 respondents. The data analysis method used is multiple linear regression analysis. The results of the analysis show that simultaneously the packaging design, promotion and brand image variables have a significant effect on consumer buying interest, this is evidenced by the significance value of 0,000 or less than 0.05 and F 127,634> ft. 1.98. The results of the analysis partially indicate that the variable promotion of significance value $0.002<0.05$, which means that it has a significant effect on buying interest and brand image significance value $0,000<0.50$ which means that it significantly influences buying interest, while packaging design variables partially significance value 0.542 . $>0.50$ which means does not significantly influence buying interest.
\end{abstract}

Keywords: Packaging Design, Promotion, Brand Image, Buying Interest

\section{INTRODUCTION}

In the current era, many consumers are increasingly selective in their behavior to consume and choose the products they want and need. Therefore, entrepreneurs must be smarter and more innovative in creating products that suit consumers' tastes and must be smart in creating packaging designs. where packaging design can attract interest in buying products. Competition in the business world is getting tougher, especially in marketing goods and services, promotional capacity as a medium of information in delivering messages to consumers plays an important role in business success. Glek-Glek Tea is a private business founded by Mr. Denny Yusuf Agastyan located on J1. DiponegoroNganjuk in May 2018 had five employees. This business is engaged in tea-based beverages from Thailand. At present, TehGlek-Glek has opened two branches in Nganjuk. The increasingly tight competition that exists, especially competition from similar companies, makes companies increasingly demanded to move faster in attracting consumers. So companies that apply the marketing concept need to look at consumer behavior in the factors that influence buying interest in the product marketing business. One way to achieve company goals is to know what the needs and desires of consumers or target markets and provide satisfaction that are expected to be more effective and efficient than competitors (Kotler, 1996). Promising opportunities and opportunities from the market share of Thai tea drinks combined with this new flavor and also supported by the abundance of available resources make Thai beverage producers increasingly developed and known. This results in the possibility that in the beverage industry there is a very tight business competition for marketers and producers of these products.

Influence of Packaging Design, Promotion and Brand Image on Consumer Buying Interest (Study Case of Consumers Glek-Glek Tea Nganjuk)

Ratna Ningtyas Nur Romadhona, Nyoman Sudapet, Hamzah Denny Subagio 


\section{LITERATURE REVIEW}

\section{Packaging Design}

Packaging is a creative design that links shape, structure, material, color, image, typography and design elements with product information so that the product can be marketed. Packaging is used to wrap, protect, send, issue, store, identify and distinguish a product on the market. (Klimchuk and Krasovec, 2006: 33). The indicators used are:

1) Graphic design

2) Design structure

3) Product information

\section{Promotion}

Promotion is an effort or company activity in influencing actual consumers and potential consumers so that they want to make purchases on products offered, now or in the future, Sistaningrum (2002: 98). The indicators used are:

1) Frequency of sales

2) Quality of promotion

3) Timeliness

4) Promotion time

\section{Brand Image}

Brand image, tjiptono $(2008 ; 49)$ is a description of the association of consumer confidence in a particular brand. The indicators used are:

1) Image maker

2) User image

3) Product Image

\section{Buying interest}

The consumer's buying interest is something that arises after receiving a problem from the product he sees, from there arises an interest in trying the product until finally the desire arises to buy so that it can have it (Kotler 2005: 205). The indicators used are:

1) Transactional interest

2) Refresh Interest

3) Preferential Interest

4) Explorative Interest

Influence of Packaging Design, Promotion and Brand Image on Consumer Buying Interest (Study Case of Consumers Glek-Glek Tea Nganjuk)

Ratna Ningtyas Nur Romadhona, Nyoman Sudapet, Hamzah Denny Subagio 


\section{RESEARCH METHODS}

\section{Types of research}

This research is a type of quantitative research that uses a descriptive approach. Quantitative research is a research method based on positivity, used to examine the population or certain semple, data collection techniques in general are done randomly, research instrument data collection, data analysis is quantitative / statistical in order to test predetermined hypotheses (Sugiono, 2008: 13). This descriptive study aims to provide a detailed and very accurate picture, finding new data that is contrary to old data, creating a series of theories or classifying types (Neuman, 2013: 44).

\section{Population and Stamp}

Population according to Sugiyono (2011: 80) is a generalization area consisting of objects or subjects that have certain qualities and characteristics that are appointed by researchers to be studied and then added conclusions. Population in this study are consumers of Glek-Glek Tea JalanDiponegoroNganjuk whose numbers are not known. The sampling technique in this study used an accidental sampling technique that is sampling taken from all consumers of Glek-Glek Tea on JalanDiponegoroNganjuk that was met by researchers at the time of distributing the questionnaire. The number of samples in this study were 100 respondents.

\section{Data collection technique}

Data collection techniques used in this study were library research and questionnaires. Library research is the collection of theoretical data by examining various literature and other library materials related to the problem under study. Questionnaires to obtain the data needed, the data collection method used is a questionnaire that is giving a list of questions to respondents in the hope that the respondent will respond to the question. Measurement of variables is done by the Likert scale using the scoring method.

\section{Data analysis technique}

In this study using multiple linear regression analysis to determine how much influence the independent variable (independent) on the dependent variable (dependent) for changes from each increase or decrease in the independent variable that will affect the related variables. Multiple linear regression analysis is used to analyze the influence of independent variables (packaging design, promotion, brand image) on the dependent variable, namely buying interest. The mathematical formulas of multiple linear used in this study are:

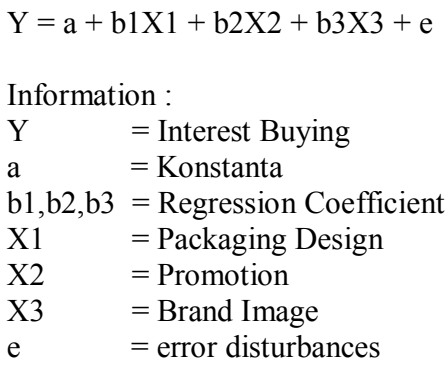

\section{Reliability Test}

According to Sugiono (2005), reliability is a measurement or measuring instrument that has consistency if done with the measuring instrument in a repetitive manner. This technique is done with SPSS 18 which provides facilities for measuring CronbachAlpha $(\alpha)$. If the Alpha coefficient results are greater than the $60 \%$ significance level or 0.6 then the questionnaire is reliable.

Influence of Packaging Design, Promotion and Brand Image on Consumer Buying Interest (Study Case of Consumers Glek-Glek Tea Nganjuk)

Ratna Ningtyas Nur Romadhona, Nyoman Sudapet, Hamzah Denny Subagio 


\section{Validity test}

Ghozali (2009) states that the validity test is used to measure the validity or validity of a questionnaire. A questionnaire is said to be valid if the question in the questionnaire is able to reveal something that will be measured by the questionnaire. Usually the minimum requirement to be considered fulfills the requirements if $r$ count $>$ r table.

\section{Normal Distribution Test}

Before the normal distribution test is carried out, it must first be obtained from the dependent and independent variables. Each variable is a sale averaged from each of the indicators. How to test a normal distribution using the normal Kolmogorov and Smirnov distribution tests, the rule is if a significant value is greater than 0.05 then the variable is normally distributed

\section{Analysis of Multiple Linear Regression}

The method of multiple linear regression analysis according to Sugiyono (2014-277) that: Multiple linear regression analysis intends to analyze the significance of independent effects on dependents both simultaneously and partially by reading the output of multiple linear regression results.

\section{Determination Test $\mathbf{R}$ and Adjusted $\mathbf{R}$ Square $\left(\mathbf{R}^{2}\right)$}

According to Imam Ghozali (2013-97) the determinant coefficient $\left(\mathrm{R}^{2}\right)$ basically measures how far the ability of the model to explain the variation of independent variables. Determinant values are zero and one. Small $\mathrm{R}^{2}$ values mean the ability of independent variables to explain variations in the dependent variable is very limited How to measure it if $\mathrm{R}$ is greater than 0.5 , the study shows that the independent variable has a significant effect on the dependent variable. While the adjusted $\mathrm{R}^{2}$ shows how much the percentage of independent variables on the dependent variable. Furthermore, other variables that influence the dependent variable but not examined in this study can be known by reducing the number $100 \%$ - adjusted $\mathrm{R}^{2}$.

\section{Hypothesis testing}

\section{F test (ANOVA test or simultaneous test)}

The $\mathrm{F}$ test is used to determine whether the independent variables together influence significantly the dependent variable. Test criteria, if FHITUNG $>\mathrm{F}^{\mathrm{TaBEL}}$ or if $\alpha<5 \%$. Then Ho is rejected, if $\mathrm{F}^{\mathrm{HITUNG}}<\mathrm{F}^{\mathrm{TaBEL}}$, or if $\alpha>$ $5 \%$, Ho is accepted.

\section{T test (Partial Test)}

Partial test is used to determine the effect of each independent variable significantly on the dependent variable. The $\mathrm{t}$ test criteria used for Ho rejected are if tcount $>\mathrm{t}$ table, or -table $<-\mathrm{t}$ table or if $\alpha<5 \%$ and Ho is accepted if tcount $<$ ttable, or if -thcount $>$-ttable, or if $\alpha>5 \%$.

\section{Classic assumption test}

\section{Multicollinearity Test}

The multicollinearity test used to test the regression model found no correlation between independent variables. A good regression model should not have a correlation between the independent variables. The guidance of a multiko-free regression model is to have a VIF value around 1 and have a Tolerance number close to 1.

Influence of Packaging Design, Promotion and Brand Image on Consumer Buying Interest (Study Case of Consumers Glek-Glek Tea Nganjuk)

Ratna Ningtyas Nur Romadhona, Nyoman Sudapet, Hamzah Denny Subagio 


\section{Heteroscedasticity Test}

Heteroscedasticity test aims to test whether a regression model occurs inequality of residual variance from one observation to another observation. If the residual variance from one observation to another is fixed, then that is Homoscedasticity. And if the variance is different, it is called heteroscedasticity ... A good regression model is not heteroscedasticity (SinggihSantoso, 2010).

\section{Normality Test of Regression Equations}

The normality test aims to test whether in a regression model the residual value of the regression has a normal distribution. If the distribution of the residual values cannot be considered a normal distribution, then there is a problem with the assumption of normality (SinggihSantoso, 2010).

\section{RESEARCH RESULTS AND DISCUSSION}

\section{Reliability Test}

Tabel 1. Result Reliability Test

Reliability Statistics

\begin{tabular}{cc}
\hline Cronbach's Alpha & N of Items \\
\hline .955 & 14 \\
\hline Sumber : Data Output SPSS &
\end{tabular}

The data of this study have cronbach's alpha 0.955 which means that it is greater than 0.60 , then the research data above is stated to be reliable and reliable.

\section{Validity Testing}

Tabel 2. Result Validity Test

\begin{tabular}{llccc}
\hline No. & \multicolumn{1}{c}{ Variable } & Korelasi & R tabel & Remaks \\
\hline & Packaging Design & & & \\
1 & X1.1 & 0,95 & 0,1654 & VALID \\
2 & X1.2 & 0,955 & 0,1654 & VALID \\
3 & X1.3 & 0,956 & 0,1654 & VALID \\
& Promotion & & & \\
1 & X2.1 & 0,952 & 0,1654 & VALID \\
2 & X2.2 & 0,952 & 0,1654 & VALID \\
3 & X2.3 & 0,95 & 0,1654 & VALID \\
4 & X2.4 & 0,953 & 0,1654 & VALID \\
& Brand Image & & &
\end{tabular}

Influence of Packaging Design, Promotion and Brand Image on Consumer Buying Interest (Study Case of Consumers Glek-Glek Tea Nganjuk)

Ratna Ningtyas Nur Romadhona, Nyoman Sudapet, Hamzah Denny Subagio 


\begin{tabular}{llccc}
1 & $\mathrm{X} 3.1$ & 0,95 & 0,1654 & VALID \\
2 & $\mathrm{X} 3.2$ & 0,953 & 0,1654 & VALID \\
3 & $\mathrm{X} 3.3$ & 0,95 & 0,1654 & VALID \\
& Interest buying & & & \\
1 & $\mathrm{Y} 1$ & 0,956 & 0,1654 & VALID \\
2 & $\mathrm{Y} 2$ & 0,952 & 0,1654 & VALID \\
3 & $\mathrm{Y3}$ & 0,95 & 0,1654 & VALID \\
4 & $\mathrm{Y} 4$ & 0,95 & 0,1654 & VALID \\
\hline
\end{tabular}

Sumber : Data Output SPSS

The results showed that all variables to measure Packaging Design (X1), Promotion (X2), Brand Image (X3) and Purchase Interest (Y) in this study. That all correlation values show greater than R table and stated all valid variables.

\section{Normal Distribution Test}

The method of measuring generally uses the normal Kolmogorov and Smirnov distruibusi test. The rule is if the significance value is $>0.05$ then the variable is normally distributed.

Table 3. Normal Distribution Testing

\begin{tabular}{|c|c|c|c|c|c|}
\hline \multicolumn{6}{|c|}{ One-Sample Kolmogorov-Smirnov Test } \\
\hline & & $\mathrm{X} 1$ & $\mathrm{X} 2$ & $\mathrm{X} 3$ & $\mathrm{Y}$ \\
\hline $\mathrm{N}$ & & 100 & 100 & 100 & 100 \\
\hline \multirow[t]{2}{*}{ Normal Parameters ${ }^{\mathrm{a}, \mathrm{b}}$} & Mean & 30.756 & 29.622 & 29.968 & 30.586 \\
\hline & Std. Deviation & .78406 & .79254 & .81746 & .80180 \\
\hline \multirow[t]{3}{*}{ Most Extreme Differences } & Absolute & .119 & .111 & .098 & .124 \\
\hline & Positive & .081 & .056 & .071 & .076 \\
\hline & Negative & -.119 & -.111 & -.098 & -.124 \\
\hline Kolmogorov-Smirnov Z & & 1.186 & 1.105 & .977 & 1.242 \\
\hline Asymp. Sig. (2-tailed) & & .120 & .174 & .295 & .092 \\
\hline
\end{tabular}

\footnotetext{
a. Test distribution is Normal.

b. Calculated from data.
}

Source : Data Output SPSS

The results showed that Packaging Design (X1), Promotion (X2), Brand Image (X3) and Purchase Interest $(\mathrm{Y})$ showed a significance value of $>0.05$ and were declared to be normally distributed.

Influence of Packaging Design, Promotion and Brand Image on Consumer Buying Interest (Study Case of Consumers Glek-Glek Tea Nganjuk)

Ratna Ningtyas Nur Romadhona, Nyoman Sudapet, Hamzah Denny Subagio 
Multiple Linear Regression

Determination Coefficient R Test and Adjusted R Square

Tabel4. Result Determination Coefficient R dan Adjusted R Square

Model Summary

\begin{tabular}{|c|c|c|c|c|}
\hline Model & $\mathrm{R}$ & R Square & $\begin{array}{l}\text { Adjusted R } \\
\text { Square }\end{array}$ & $\begin{array}{l}\text { Std. Error of the } \\
\text { Estimate }\end{array}$ \\
\hline 1 & $.894^{\mathrm{a}}$ & .800 & 79 & \\
\hline
\end{tabular}

a. Predictors: (Constant), X3, X1, X2

Sumber : Data Output SPSS

The results showed that the value of $\mathrm{R}(0.894)<0.05$ stated that the variable $\mathrm{X}$ had a significant effect on the variable Y. Adjusted $\mathrm{R}^{2}$ showed that $80 \%$ was influenced by the dependent variables, and $20 \%$ was influenced by other variables not examined in this study .

\section{Hypothesis testing}

Uji F Test (Simultaneos)

Tabel5.UjiFTest (simultaneous)

\begin{tabular}{|c|c|c|c|c|c|c|}
\hline \multicolumn{7}{|c|}{ ANOVA $^{b}$} \\
\hline Model & & Sum of & & Mean & & \\
\hline \multirow[t]{3}{*}{1} & Regression & 50.887 & 3 & 16.962 & 127.634 & $.000^{\mathrm{a}}$ \\
\hline & Residual & 12.758 & 96 & .133 & & \\
\hline & Total & 63.646 & 99 & & & \\
\hline
\end{tabular}

a. Predictors: (Constant), X3, X1, X2

b. Dependent Variable: Y

Sumber : Data Output SPSS

The results showed that Fcount $=127.634$ while Ftable obtained was 1.98 . Thus Fcount $127.634>$ Ftable 1.98. So that it can be concluded that Packaging Design (X1), Promotion (X2), and Brand Image (X3) simultaneously have a significant effect on Purchase Interest (Y) on Glek-Glek Tea Surabaya.

Influence of Packaging Design, Promotion and Brand Image on Consumer Buying Interest (Study Case of Consumers Glek-Glek Tea Nganjuk)

Ratna Ningtyas Nur Romadhona, Nyoman Sudapet, Hamzah Denny Subagio 


\section{Uji T Test (Parsial)}

Tabel6. Result UjiT Test (Parsial)

Coefficients $^{\mathrm{a}}$

\begin{tabular}{|c|c|c|c|c|c|c|}
\hline \multirow{2}{*}{\multicolumn{2}{|c|}{ Model }} & \multicolumn{2}{|c|}{ Unstandardized Coefficients } & $\begin{array}{l}\text { Standardized } \\
\text { Coefficients }\end{array}$ & \multirow[b]{2}{*}{$\mathrm{t}$} & \multirow[b]{2}{*}{ Sig. } \\
\hline & & B & Std. Error & Beta & & \\
\hline 1 & (Constant) & .318 & .154 & & 2.065 & .042 \\
\hline & X1 & .048 & .079 & .047 & .612 & .542 \\
\hline & $\mathrm{X} 2$ & .366 & .114 & .362 & 3.220 & .002 \\
\hline & X3 & .503 & .117 & .513 & 4.282 & .000 \\
\hline
\end{tabular}

a. Dependent Variable: Y

Sumber : Data Output SPSS

The results showed that the value of $t$ count Packaging Design variable (X1) was 0.612, Promotion variable (X2) was 3.220, and Brand Image (X3) was 4.282.

Classic assumption test

Multicollinearity Test

Tabel 7. Result Multikolinerarity Test

\section{Coefficients $^{\mathrm{a}}$}

\begin{tabular}{ccrc}
\hline \multicolumn{2}{l}{ Model } & \multicolumn{2}{c}{ Collinearity Statistics } \\
\cline { 3 - 4 } & & Tolerance & \multicolumn{1}{l}{ VIF } \\
\hline 1 & X1 & .353 & 2.837 \\
& X2 & .165 & 6.060 \\
& X3 & .146 & 6.868 \\
\hline
\end{tabular}

a. Dependent Variable: Y

Sumber : Data Output SPSS

The results showed that the regression model did not experience multicollinearity disorders. This can be seen in a tolerance value greater than 0.1 . The VIF calculation results also show that the VIF value of each dependent variable is less than 10. So it can be concluded that there is no multicollinearity between independent variables in the regression model

Influence of Packaging Design, Promotion and Brand Image on Consumer Buying Interest (Study Case of Consumers Glek-Glek Tea Nganjuk)

Ratna Ningtyas Nur Romadhona, Nyoman Sudapet, Hamzah Denny Subagio 


\section{Heteroscedasticity Test}

Tabel 8.Result Spearman Test(Heteroskedasticity)

\begin{tabular}{|c|c|c|c|c|c|c|}
\hline \multicolumn{7}{|c|}{ Correlations } \\
\hline & & & Abs_RES & $\mathrm{X} 1$ & $\mathrm{X} 2$ & $\mathrm{X} 3$ \\
\hline \multirow[t]{12}{*}{ Spearman's rho } & Abs_RES & Correlation Coefficient & 1.000 & .115 & .087 & .070 \\
\hline & & Sig. (2-tailed) & . & .254 & .388 & .489 \\
\hline & & $\mathrm{N}$ & 100 & 100 & 100 & 100 \\
\hline & $\mathrm{X} 1$ & Correlation Coefficient & .115 & 1.000 & $.710^{* *}$ & $.770^{* *}$ \\
\hline & & Sig. (2-tailed) & .254 & . & .000 & .000 \\
\hline & & $\mathrm{N}$ & 100 & 100 & 100 & 100 \\
\hline & $\mathrm{X} 2$ & Correlation Coefficient & .087 & $.710^{* *}$ & 1.000 & $.895^{* *}$ \\
\hline & & Sig. (2-tailed) & .388 & .000 & . & .000 \\
\hline & & $\mathrm{N}$ & 100 & 100 & 100 & 100 \\
\hline & $\mathrm{X} 3$ & Correlation Coefficient & .070 & $.770^{* *}$ & $.895^{* *}$ & 1.000 \\
\hline & & Sig. (2-tailed) & .489 & .000 & .000 & . \\
\hline & & $\mathrm{N}$ & 100 & 100 & 100 & 100 \\
\hline
\end{tabular}

**. Correlation is significant at the 0.01 level (2-tailed).

Sumber : Data Output SPSS

Based on the table above, to test heteroscedasticity using the spearman test. Which is where if the sig value must be greater than 0.05 then heteroscedasticity does not occur. And the results of this study from packaging design (X1) sig value is 0.254 , promotion (X2) sig value is 0.388 , and brand image (X3) sig value is 0.489 . And the results of data processing show above 0.05 , it is stated that there is no heteroscedasticity.

\section{Normality Test}

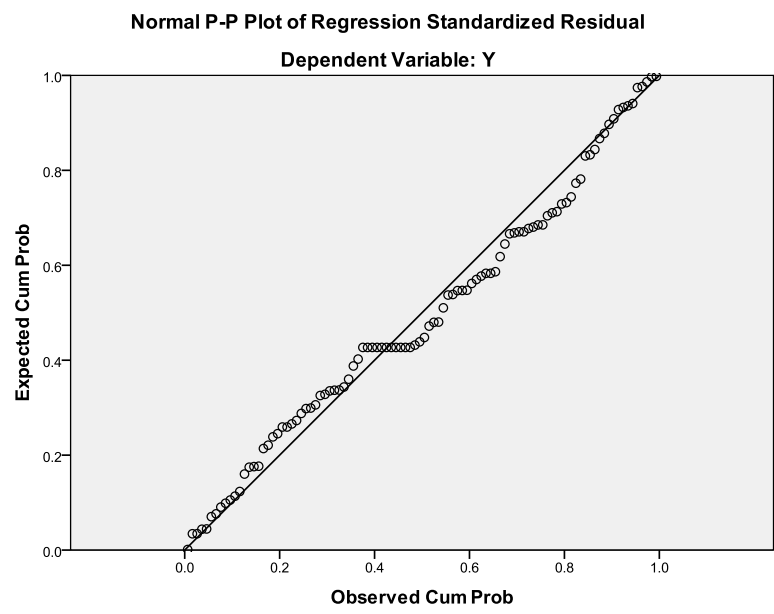

Source : Data Output SPSS

Influence of Packaging Design, Promotion and Brand Image on Consumer Buying Interest (Study Case of Consumers Glek-Glek Tea Nganjuk)

Ratna Ningtyas Nur Romadhona, Nyoman Sudapet, Hamzah Denny Subagio 
In principle, normality can be detected by looking at the spread of data (dots) on the diagonal axis of the graph or by looking at the residual histogram. In the picture it can be seen that the standardized normal probability plot of regression graph shows a normal graph pattern. This can be seen from the points that spread around the diagonal line and the diagonal line from the lower left to the right. Then it can be concluded that the regression model is feasible because it meets the assumptions of normality.

\section{Testing the Effect of Packaging Design on Buying Interests}

The test results obtained $t$ value calculated for packaging design variables on buying interest shows the value of $t$ count $=1.612<$ from $t$ table 1.98 with a significance of $0.542>0.05$, which means that packaging design partially does not significantly influence buying interest.

\section{Testing of the effect of promotion on buying interest}

The test results obtained by the value of $t$ count for the promotion variable on buying interest shows the value of $\mathrm{t}$ arithmetic $=3.220>$ from $\mathrm{t}$ table 1.98 with a significance of $0.002<0.05$, which means that packaging design partially has a significant effect on buying interest.

\section{Testing the Effect of Brand Image on Buying Interests}

The test results obtained by the value of $t$ arithmetic for the brand image variable against buying interest shows the value of $t$ count $=4.282>$ from $t$ table 1.98 with a significance of $0,000<0.05$, which means that the brand image partially has a significant effect on buying interest.

\section{Effect of Packaging Design, Promotion and Brand Image on Buying Interests}

Based on the results of simultaneous hypothesis testing (Test F) of independent variables (free), namely packaging design, promotion and brand image simultaneously influence the dependent variable (bonded) buying interest. This is evidenced from the significance value of 0,000 or less than 0.05 and Fcount $=127.634$ while the value of Ftable is 1.98. Thus Fcount 127,734>Ftable 1.98

\section{CONCLUSION}

Based on the SPSS version 18.00 output obtained a significance value of X1 $=0.542>0.05$ so that the conclusions partially the packaging design variable (X1) did not significantly influence the buying interest (Y) of Glek-GlekTeaNganjuk consumers. Significance value $\mathrm{X} 2=0.002<0.05$ so that the conclusions partially promotion variable (X2) have a significant effect on buying interest (Y) of consumers Glek-GlekTeaNganjuk. The significance value of $\mathrm{X} 3=0,000<0,05$, so that the conclusions in the partial brand image variable (X3) have a significant effect on buying interest (Y) of consumers of Glek-Glek Tea Nganjuk.

Packaging design variables (X1), promotions (X2) and Brand Image (X3) have a simultaneous effect on buying interest $(\mathrm{Y})$ with a significance value smaller than 0.05 , which is equal to 0,000 .

\section{REFERENCES}

\section{P, K. (2005). Manajemen Pemasaran. Jakarta: PT. Indeks Kelompok Gramedia.}

Prasetyaningtyas, I. (2014). Pengaruh Iklan dan Kemasan Terhadap Niat Beli Yang Dimediasi Oleh

Citra Merek. Jurnal Ekonomi \& Bisnis Vol. 8, No. 1, 27-38.

Influence of Packaging Design, Promotion and Brand Image on Consumer Buying Interest (Study Case of Consumers Glek-Glek Tea Nganjuk)

Ratna Ningtyas Nur Romadhona, Nyoman Sudapet, Hamzah Denny Subagio 
Salfina, L., \& Gusri, H. (2018). Pengaruh Citra Merek, Kualitas Produk dan Harga Terhadap Minat Beli Pakaian Anak-anak Studi Kasus Toko Rizky dan Afdal Pariaman. Jurnal Indovisi Vol. 1, No.1, 83-100.

Santoso, S. (2010). SPSS Statistik Non Prametrik. Jakarta: Gramedia.

Satria, A. A. (2017). PENGARUH HARGA, PROMOSI, DAN KUALITAS PRODUK TERHADAP MINAT BELI KONSUMEN PADA PERUSAHAAN A-36. Jurnal Manajemen dan Start-Up Bisnis, 45 - 53.

Satria, A. A. (2017). PENGARUH HARGA, PROMOSI, DAN KUALITAS PRODUK TERHADAP MINAT BELI KONSUMEN PADA PERUSAHAAN A-36. Jurnal Manajemen dan Start-Up Bisnis Vol.2, No.1, 45 $-53$.

Sopwa, N., \& Banin, Q. A. (2015). Analisis Pengaruh Perceived Harga, Kemasan dan Daya Tarik Iklan Televisi Terhadap Minat Beli Konsumen Produk Rokok Djarum Super di Bumiayu. JURNAL BISNIS DAN MANAJEMEN (JBIMA) Vol. 3, No. 2, 154 - 164.

Sugiyono. (2004). Metode Penelitian Bisnis. Bandung: CV. Alvabeta.

Sugiyono. (2009). Metode Penelitian Bisnis (Pendekatan Kuantitatif, Kualitatif, dan R\&D). Bandung: Alfabeta.

Suharto, C. A., Altje, T. L., \& Trang, I. (2016). ANALISIS PENGARUH CITRA MEREK, HARGA, DAN DAYA TARIK IKLAN TERHADAP MINAT BELI KONSUMEN PADA PT. REMAJA JAYA MOBILINDO MANADO. Jurnal EMBA Vol. 4, No. 3, 209-221.

Tjiptono. (2005). Definisi Pengertian Minat Beli.

Yamin, S., \& Kurniawan, H. (2009). SPSS "Complete Teknik Analisis Statistik Terlengkap" SPSS. seri 1. Jakarta: Salemba Empat.

Influence of Packaging Design, Promotion and Brand Image on Consumer Buying Interest (Study Case of Consumers Glek-Glek Tea Nganjuk)

Ratna Ningtyas Nur Romadhona, Nyoman Sudapet, Hamzah Denny Subagio 